References

1. Gostishchev V. K. The basic principles of etiotropic tyherapy of chronic osteomyelitis. Surgery. 1999;(9):3842

2. Nikitin G. D., Rak A. V., Lynnic S. A., Nikolayev V. F., Nikitin D. G. Bone and muscle-bone grafting in treating chronic osteomyelitis and pyogenic pseudarthrosis. SPb., 2002.

3. Kutin A. A., Mosiyenko N. I. Hematogenic osteomyelitis of adults. M., 2000.

4. Noskov V. N., Agarkov V. P., Gostintsev A. A., Dzyuba G. G., Polozhentsev A. A. Practice of treating patients with chronic osteomyelitis of long bones. Pyogenic complications in traumatology and orthopedics: Materials of scientific-practical conference. Novosibirsk, 2005. P. 25-26

5. Chechnyev Y. Y., Yakushenko V. K., Chekanov M. N. Rutkovsky Y. A., Morozov A. Y. [et al.]. The method of filling sequestral cavities with porous fine-grain titanium nickelide in treating chronic osteomyelitis. Implants with shape memory. 2004;(1-2):19-21.

6. Borisov I. V., Amiraslamov Y. A., Blatun L. A. Antibacterial therapy for osteomyelitis (systematized review). Antibiotics and chemotherapy. 2003;(9):37-40.
7. Fomichev N. G. New technologies in spine surgery with the use of implants with shape memory. Tomsk, 2002.

8. Gunter V. E., Dambayev G. T., Sysolyatin P. G. Medical materials and implants with shape memory. Tomsk, 2002.

9. Iryanov Yu. M., Strelkov N. S., Kiryanov N. A., Dyuryagina $\mathrm{O}$. V. Treatment of cavitary bone defects under implantation of the mesh structures made of titanium nickelide. Medical News of North Caucasus 2017;12(2):152-156. doi: 10.14300/mnnc.2017.12043

10. Radkevich A. A., Khodorenko V. N., Gunter V. E. Reparative osteogenesis in bone defects after restoration with porous fine-grain titanium nickelide. Implants with shape memory. 2005; (1-2):30-34.

11. Strelkov N. S., Kiryanov N. A., Shklyaev P. O. Pathomorphology and mineral composition of bone in experimental osteomyelitis. Medical News of North Caucasus. 2015;10(4):415-418. doi: 10.14300/ mnnc.2015.10101

12. Cripps M., Shirtliff M. E., Mader J. T. The treatment of osteomyelitis with hydroxyappatite antibiotic implant in a rabbit model. 8th Intersc. Conf. Antimicrobial Agents Chemother. San Diego, 1998.

About authors:

Stofin Andrey Sergeevich, MD; Associate Professor, Department of general surgery;

tel.: +73832767464; e-mail: department.of.general.surgery@gmail.com

Shegolev Michail Borisovich, MD; Associate Professor, Department of general surgery;

tel.: +73832767464; e-mail: department.of.general.surgery@gmail.com

Trushin Pavel Victorovich, MD, CMSc; Associate Professor, Department of general surgery; tel.: +79039038682; e-mail: tpv1974@rambler.ru Golovnev Vladimir Andreevich, MD; PhD, Professor, Professor of Department of general surgery;

tel.: +73832767464; e-mail: department.of.general.surgery@gmail.com

Golovnev Andrey Vladimirovich, MD, CMSc; Associate Professor, Department of general surgery;

tel. +73832767464; e-mail: department.of.general.surgery@gmail.com

Shtofin Sergey Gridorevich, MD; PhD, Professor, Head of Department of general surgery;

tel. +73832767464; e-mail: department.of.general.surgery@gmail.com

(C) Group of authors, 2017

UDC 636.32:616.11.71-007

DOI - https://doi.org/10.14300/mnnc.2017.12091

ISSN - 2073-8137

\title{
OSTEOPOROTIC SHEEP MANDIBULAR MODEL FOR COMPARATIVE ALVEOLAR BONE HEALING RESEARCH
}

\author{
Sirak S. V. 1, Shchetinin E. V. 1, Bobryshev D. V. ' , Fritsch T. ${ }^{2}$, Giesenhagen B. 3 , \\ Petrosyan G. G. 1, Didenko N. N. 1, Romanenko'R. G. 1, Grimm W.-D. 1,4 \\ 1 Stavropol State Medical University, Russian Federation \\ 2 University of Arad, Romania \\ 3 University of Frankfurt am Main, Germany \\ 4 Witten/Herdecke University, Witten, Germany

\section{ЭКСПЕРИМЕНТААЬНАЯ МОАЕАЬ ОСТЕОПОРОЗА ААЬВЕОАЯРНЫХ КОСТЕЙ У ОВЕЦ АЛЯ СРАВНИТЕАЬНОГО ИССАЕАОВАНИЯ ОСТЕОГЕННЫХ СВОЙСТВ МАТЕРИААОВ}

\author{
С. В. Сирак ${ }^{1}$, Е. В. Щетинин ${ }^{1}$, А. В. Бобрышев ${ }^{1}$, Т. Фрич ${ }^{2}$, Б. Гизенхаген ${ }^{3}$, \\ Г. Г. Петросян 1, Н. Н. АиАенко ', Р. Г. Романенко 1, В.-А. Гримм 1, 4
}

${ }_{1}^{1}$ Ставропольский госуАарственный меАицинский университет, Российская ФеАерация

2 Университет АраА, Румыния

3 Университет франкфурта-на-Майне, Германия

4 Университет Виттен - ХерАекке, Виттен, Германия

In the study was investigated the suitability of the mandibular ridge in osteoporotic sheep for comparative dental implant research, to establish histological protocols for this model, to study the effect of variations in healing of tooth extraction sockets and of an acute $12 \mathrm{~mm}$ bone defects. The hypothesis tested was the post-extraction osteoporotic sheep mandible and the acute $12 \mathrm{~mm}$ bone defect in osteoporotic sheep is a suitable model for comparative dental 
implant research. Seven young female sheep with an average body weight of $30 \mathrm{~kg}$ have been used in this proof of principle study. Six months prior to the studies start, animals had been neutered by ovariectomy to induce osteoporosis. In the first phase, extraction of the incisors was performed bilaterally in each osteoporotic sheep. Following tooth extraction, in accordance with the literature two standardized box-shaped defects (12 $\mathrm{mm}$ acute bone defects) were surgically created at the buccal aspect of the alveolar ridge in the buccal sextant in a split-mouth design. As the second phase after 12 weeks, block sections were obtained from the experimental sites. Descriptive histological analysis on non-decalcified and decalcified sections was carried out. Bone density (BMD) was measured using radiographic images and initial quantitative analysis was provided to study the bone architecture of our Osteoporotic Sheep Model. Significant microstructural evolutions were found on the bone compartment biopsies. The bone volume fraction (BV/ TV) decreased by approximately $25 \%$ at six months post-ovariectomy. Histologic analysis of the periodontal/bone compartment sections stained with different stains revealed typical changes in the periodontal/bone compartments of the osteoporotic sheep. At 12 weeks, defect healing was mainly characterized by an ongoing bone formation and mineralization. Bone loss at investigated anatomical sites was in excess of $25 \%$ which is sufficient to categorize these animals as osteoporotic supporting the stated hypothesis and suggests that the mechanism of bone loss could differ temporally as well as anatomically.

\section{Keywords: osteoporotic sheep model, bone densification, qualitative histology}

Были изучены возможности использования области гребня нижней челюсти остеопорозных овец для проведения сравнительного исследования установки дентальных имплантатов, изучения различных вариантов заживления постэкстракционных и артифициальных костных дефектов размером до 12 мм при оценке остеогенного потенциала материалов различного происхождения. Семь молодых овец использованы в данном исследовании для доказательства релевантности модели. За шесть месяцев до начала исследования 7 молодых овец со средней массой тела 30 кг были стерилизованы путем овариэктомии для индуцирования остеопороза. Вначале проведена билатеральная экстракция резцов у всех животных, после чего на щечном крае альвеолярного гребня были созданы 2 стандартизированных дефекта кубической формы (12 мм) по одному с каждой стороны. Через 12 недель получены блоки из экспериментальных областей. Выполнен описательный гистологический анализ декальцифицированных и недекальцифицированных срезов, измерена плотность кости (BMD) с использованием рентгенографических изображений и проведен ее первоначальный количественный анализ с целью изучения костной архитектуры. Через 12 недель заживление дефекта характеризовалось главным образом продолжающимся формированием кости и минерализацией. Потери костной ткани в исследуемых областях через 6 месяцев после овариэктомии составили 25 \%, что позволяет судить о наличии остеопороза у данных животных. Это также подтверждает выдвигаемую гипотезу, что механизм ремоделирования костной ткани может отличаться по времени и анатомическим признакам.

Ключевые слова: модель остеопороза у овец, плотность костей, гистология

$\mathbf{R}$ eproducible and suitable animal models are required for in vivo experiments to investigate newly developed dental implants and new osteoinductive biomaterials for augmentation of alveolar bones at risk for changes due to the aging process (FDA 1994) [5]. Especially different aspects of alveolar bone healing supported by stem cell applications can be studied in animal models [7, 19].

The jaw of domestic sheep has been used as a suitability model on the for dental implant research [2]. Any animal model used for dental implant research should be consist of both cortical and cancellous bone, and resemble human mandible with respect to physical dimensions, embryological development and physiology [11].

A current clinical challenge in the field of dental implantology is to obtain a stable implant fixation in weak bone situations of elderly patients. The life expectancy of patients has progressively increased over the last century and will continue to do so for many years to come. As a direct consequence, many more patients need dental implantology as the quality of their alveolar bone progressively deteriorates with age. In the case of elderly patients, the early phase of osseointegration of dental implants is particularly delicate as the bone is already weak at the time of surgery. In this case, the resorption of a small amount of bone near the implant may induce a dramatic decrease in early fixation, accelerating the failure process. Therefore, questions regarding whether aging and osteoporosis negatively affect the success rate of dental implants remain unanswered. This could be due to the lack of studies comparatively evaluating the same biomaterial in healthy, aged, and osteoporotic large-sized animals.
Although there are well-established intra-oral mandibular models for dental implantology in dogs, pigs and primates, this is not the case for osteoporotic sheep. The long-bones of sheep and the maxillofacial sites in the sheep have been used to model the healing of implants, however, very little work has been done on the use of the Osteoporotic Sheep Model. However, the literature supports the contention that the sheep are suitable animal species for both bone defect and for intra-oral dental implant research and furthermore, sheep are an important species for biomedical research in the Euroasian region [4, 9, 10, 13]. Duncan [3] refers to noncritical size defects in the posterior mandible, and the use of the posterior mandible for implant placement following extraction of premolar teeth. The paper by Trisi et al. [15] refers to implant placement in the sheep iliac crest.

The aim of this study was to investigate the suitability of a post-extraction site and an acute mandibular ridge bone defect in osteoporotic sheep for comparative dental implantology, to establish preliminary histological protocols for this model, to generate baseline descriptive data in this model, to study the effect of variations in healing of tooth extraction sockets. The hypothesis tested was the acute mandible bone defect in osteoporotic sheep is a suitable model for comparative dental implant research.

Material and Methods. Osteoporotic Sheep Model. Seven young female sheep with an average body weight of $30 \mathrm{~kg}$ were used in this proof of principle study. Animal handling and surgical procedures has been approved by the local ethical committee at the Stavropol State Medical University (number 98/4, of 10/03/2011). Six months prior to the study`s start, animals had been neutered by 
ovariectomy to induce osteoporosis. The sheep were starved overnight and general anaesthesia induced with Thiopental $20 \mathrm{mg} / \mathrm{kg}$ (i. v.) and maintained with Halothane and Nitrous oxide. Aseptic techniques and sterile instruments were used throughout the procedure. Genthamycine (10 mg/kg i. m.) was administered pre-and post- operatively. In each animal, a left flank laparotomy was used to gain access to the reproductive tract, both ovaries were located and removed, and the laparotomy closed with sutures. Sheep were maintained caged, Diet supplemented with pellets for six months following ovariectomy.

Changes in the microarchitecture of alveolar bone have been investigated through 3D tomography analysis and bone density measurements 6 months after the day of ovariectomy using one control animal. The study was performed in two surgical phases. In the first phase, mandibular incisors and surrounding bone were removed and posterior surgical defects created bilaterally in each osteoporotic sheep. In phase two, the block specimens were retrieved.

All animals tolerated surgery well and regained full weight-bearing mobility by postoperative day 3. Seventeen days after the operation they were returned to external stabling until the day of experimental surgery. No signs of inflammation, gross infection, or tissue reaction were observed after ovarectomy.

Study design/Surgical protocol. Surgical Phase 1 (tooth extraction and defect creation) 6 months after ovariectomy. In the first surgery, anaesthesia was induced as described above. Two bone blocks containing incisors (split-mouth design) were carefully removed after reflection of mucoperiosteal flaps and tooth separation creating an acute-type segmental defect after 30 days + 6 months after ovarectomy (first pair of animals = 4.2 weeks), after 60 days +6 months after ovariectomy (second pair of animals $=8.5$ weeks), and after 120 days + 6 months after ovariectomy (third pair of animals = 17 weeks), overall 12 bone blocks containing teeth.

Following tooth extraction, two standardized boxtype segmental defects for each sheep $(9 \mathrm{~mm}$ in height from the crestal bone, $6 \mathrm{~mm}$ in depth from the surface of the buccal bone, and $12 \mathrm{~mm}$ in width mesio-distally) were prepared in the buccal bone with a carbide bur. The corresponding lingual bone plates were left intact. The defect sizes were standardized by the use of a periodontal probe (PCP12, Hu-Friedy Co., Chicago, IL, USA).

All osteotomy procedures were performed under copious irrigation with sterile $0.9 \%$ physiological saline. After wound closure using 4-0 sutures, the sites could heal for 12 weeks. Postoperative analgesics and antibiotics were employed and the animal were maintained in pens.

Surgical Phase II (Retrieval of specimens). After 12 weeks, block sections obtained of the experimental sites. The blocks were processed and sectioned through the center of the defect. The sections were stained with different stains for comparison. Qualitative histological analysis was carried out and the periodontal/ bone compartment and the bone compartments were compared as described in the «Histological investigation».

Monitoring of the bone mineral density (BMD) using one control animal. We have used radiographic images (TOSHIBA Aquilion 64, TSX-101A) to study the bone architecture of our Osteoporotic Sheep Model, namely, to analyze pathological bone conditions, and to study tissues structure and properties. To acquire sheep alveolar bone CT images, the CT conditions were the following: $293 \times 293 \times 100 \mu \mathrm{m}$ voxel size (virtually degraded resolution), temporal bone protocol, $120 \mathrm{kVp}, 300 \mathrm{mAs}$, $150 \mathrm{~mm}$ field of view, $12 \mathrm{~mm}$ away from distal.

In accordance to Duncan [2] distal to the lower canines is an edentulous diastema extending in a posterior direction for $2-3 \mathrm{~cm}$ and terminating at the first premolar tooth. The dimensions of this area are approximately $45 \mathrm{~mm}$ antero-posteriorly, by $10 \mathrm{~mm}$ bucco-lingually, and by $20 \mathrm{~mm}$ corono-apically (vertical height). A preliminary histological investigation (results not shown) found that this region of the mandible comprises a thin (3-5mm in width) but dense cortex of lamellar bone surrounding a sparsely-trabeculated marrow cavity which is haematogenous in young sheep but becomes progressively more adipocytic as the animal ages. As lower jaw BMD could not be determined using standard human regions of interest (ROI) a modified manual method was used. In brief the sheep head was scanned from the physiological «flexed» normal position in the sheep, without rotation to maximize visibility of the lower jaw. The head was taped to the scanner bed to prevent movement. The lower jaw was analyzed with two fixed subregions extending $3 \mathrm{~cm}$ distally from the edentulous diastema and bisecting the lower jaw along the midline.

Image segmentation has been applied to the acquired sheep alveolar bone CT images using Osiris, Version 8.0.2. Various regions window levels/widths (contrast) were applied to establish a clear separation between the cortical bone and the trabecular bone. The set up image segmentation has been performed with a contrast region, which was shown by coloring on the trabecular bone region for clear separation during 3D reconstruction. The segmented images have been accumulated layer-by-layer following the Z-plane and reconstructed as a 3D image. The Hounsfield unit (HU) measurements have been used quantitatively to express bone density of our experimental animals.

Histological investigations. Paraffin embedding. The periodontal/bone and the bone specimens were routinely processed for serial decalcified sections. Specimens were fixed in $10 \%$ neutral buffered formalin solution for 48 hours and decalcified in $5 \%$ trichloroacetic acid for 15 days, then dehydrated in ascending grades of alcohol, cleared in xylene and embedded in paraffin. Blocks were cut to $6-\mu \mathrm{m}$-thin slides and were stained with hematoxylineosin (HE), TB stain, Azan trichrome stain, and van Gieson's stain. Those stained sections were viewed with a light microscope for image analysis of the periodontal/ bone compartment and of the bone compartment.

Embedding in methylmethacrylate. Technovit 9100 New (Heraeus Kulzer, Wehrheim, Germany) is a polymethyl methacrylate (PMMA)-based technical resin as we described previously [18]. Briefly, the embedding procedure consists of four major steps:

- a general fixation and dehydration step;

- a pre infiltration step;

- an infiltration step;

- a polymerization step.

The tissue blocks were sectioned at $5 \mu \mathrm{m}$ using a RM 2155 Microtome (Leica, Bensheim, Germany) using special size D carbide knives (Slee, Mainz, Germany).

Histological analyses. The following histological investigations were performed:

- Identification of mineralized bone in the created $12 \mathrm{~mm}$ acute bone defects after 12 weeks;

- changes in the periodontium/bone compartments of the osteoporotic sheep (osteoblasts, osteocytes, osteoid, osteoclasts, vessels and collagen connective tissues) after 30 days, 60 days, and 120 days healing.

For the preliminary histological measurements of the changes in the periodontium/bone compartment of osteoporotic sheep, similar rectangles were fitted into the periodontal area and the area of the pristine bone covering the same amount of tissue in both areas.

For the preliminary evaluation of the bone remodeling in the $12 \mathrm{~mm}$ acute bone defects after 12 weeks the 
following landmarks were identified in the stained sections: the bottom of the bone defect (BD), and the coronal extension of the alveolar crest adjacent to the defect area (BC).

Results and Discussion. BMD measurements using the control animal. BMD of lower jaw in the control animal was analyzed using two fixed subregions (R1 and R2) extending $3 \mathrm{~cm}$ distally along the body of the jaw from the edentulous diastema and bisecting the lower jaw along the midline. The Hounsfield units we have found clearly support the hypothesis of Osteoporotic Sheep model used in our proof of principle study. Significant microstructural evolutions were measured on the bone compartment biopsies (Fig. 1).
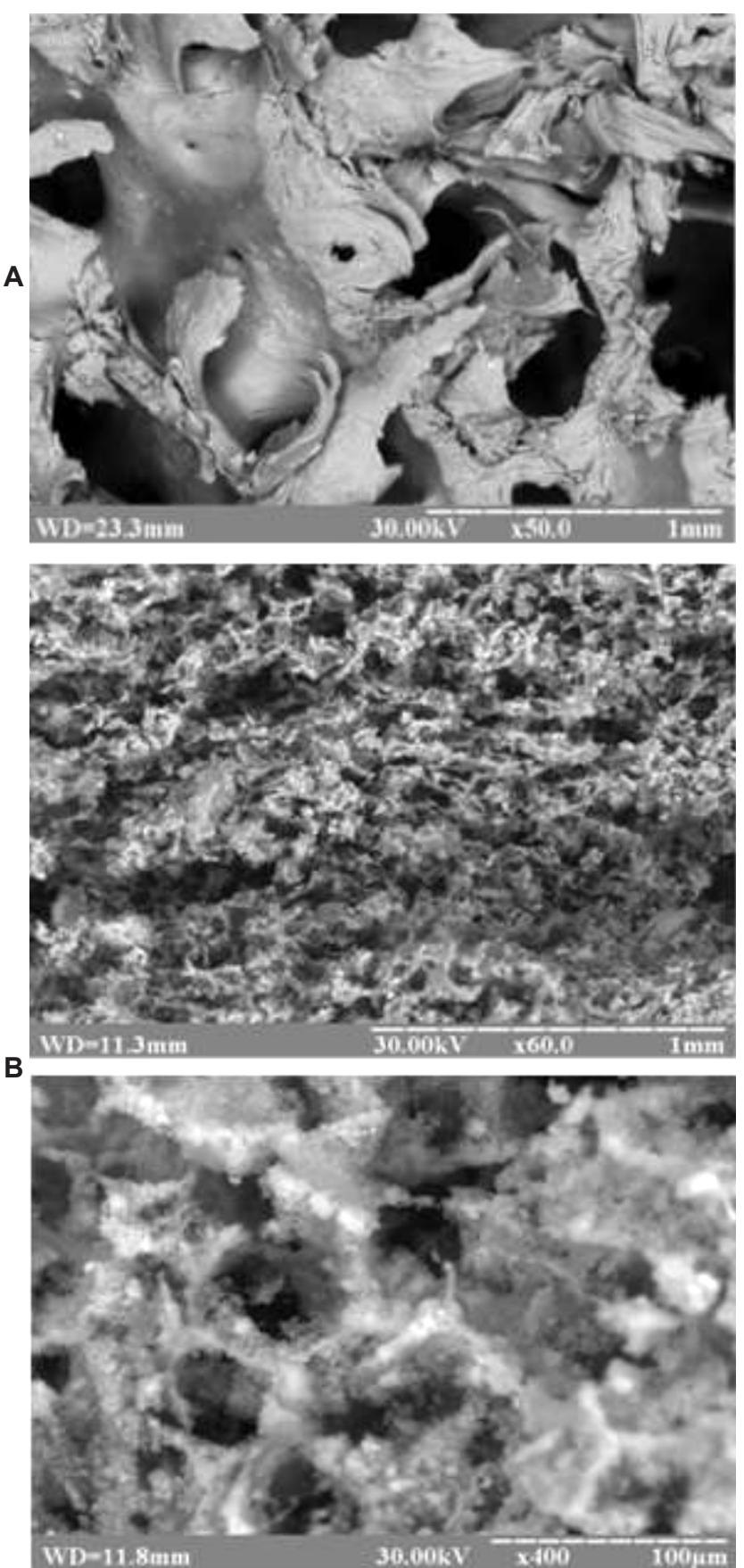

Fig. 1. Three-dimensional microtomographic description of alveolar crest biopsies microarchitecture (a) before ovariectomy and (b) 6 months after ovariectomy taken from the acute $12 \mathrm{~mm}$ bone defect. The difference illustrates the induction of osteoporosis
Histological observations. Histologic analysis of the periodontal/bone compartment sections stained with different stains revealed typical changes in the periodontium of the osteoporotic sheep. Especially on the apical area of the root surface, disarranged periodontal tissue could be observed at all time schedules (after 30 days, 60 days, and 120 days), indicating the influence of the osteoporotic processes after the ovarectomy in the cementum/ligament compartment. The periodontal/ bone compartment was surrounded by multi nucleated giant cells, showing an inflammatory response to the osteoporotic processes as an disruption of normal bone physiology due to the uncoupling of estrogen and cytokine-mediated osteoblastic control of osteoclast functions. Minor root resorption, dentinoclast-like cells and ankylosis could be observed in some specimens. In a higher resolution there was expression of mononuclear cells along the cementum-periodontium line suggesting an involvement in osteogenesis.

Toluidine blue is very well suited for detecting cell nuclei, osteoblasts and the underlying, non-calcified osteoid regions that consist mainly of chondroitin sulfate and osteocalcin. The insets show non-calcified osteoid and osteoid-forming osteoblasts at higher magnification (Fig. 2). The effect of ovarectomy on the trabecular bone was evident from low power microscopy of stained tissue sections. In all specimens of the bone compartment a typical lamellar arrangement around Haversian canals interspersed with osteocytes in lacunae, characteristic of secondary bone has been shown. No evidence of acute or chronic inflammatory infiltrate was found in any of the samples. Margins of the bone compartment revealed osteoblast-like cells and the presence of a large quantity of osteocytes in lacunae. The central portions of the bone compartment revealed fewer osteocytes with a higher number of empty lacunae; blood vessels were always present. The defects did not fully heal within the time periods used (after 12 weeks). There was marked variability in the amount of healing. In some 12-week specimens which were sectioned horizontally, woven bone had extended from the cut edges of the critical-size defect. Woven bone extended from the entire endosteal surface of the marrow cavity particularly at the margins of the defect where the endosteal woven bone merged with the less exuberant periosteal reaction. Isolated spicules of bone were seen calcifying within the soft-tissue that filled the defect. Histological examination of the animal pairs over the time schedule of the proof of principle study showed variations in healing responses between animals. Marked hyperplasia of the superior and inferior cortex occurred in all specimens. Sheep pair 1 had complete closure of the defect, although the area of regenerated bone comprising the lateral cortex was less mature and thinner than the lingual cortex. Sheep pair 2 had a thin but complete area of new bone bridging the defect. Both sub-periosteal and sub-endosteal hyperplasia occurred in the lingual cortex opposite the defect wall. Sheep pair 3 had a defect with fibrous connective tissue filling the remaining gap, however the immature nature of the bone flanking the defect suggested that incomplete healing might eventually have taken place. Sub-endosteal hyperplasia was evident (histological results not shown).

In general, histological observation demonstrated obvious differences with respect to the pattern of bone regeneration between the animal pairs. Areas of newly formed bone were characterized by an intense staining of the mineralized matrix and the numerous osteocytes located in large lacunae. In particular, TB staining indicated that new trabeculae of woven bone mainly arised from open bone marrow spaces of the adjacent 
alveolar bone defect. The subsequently formed primary spongework of woven bone covered the defect area in coronal and lateral directions. In all of the animals, the peripheral part of the spongiosa appeared to be higher mineralized than in the center.
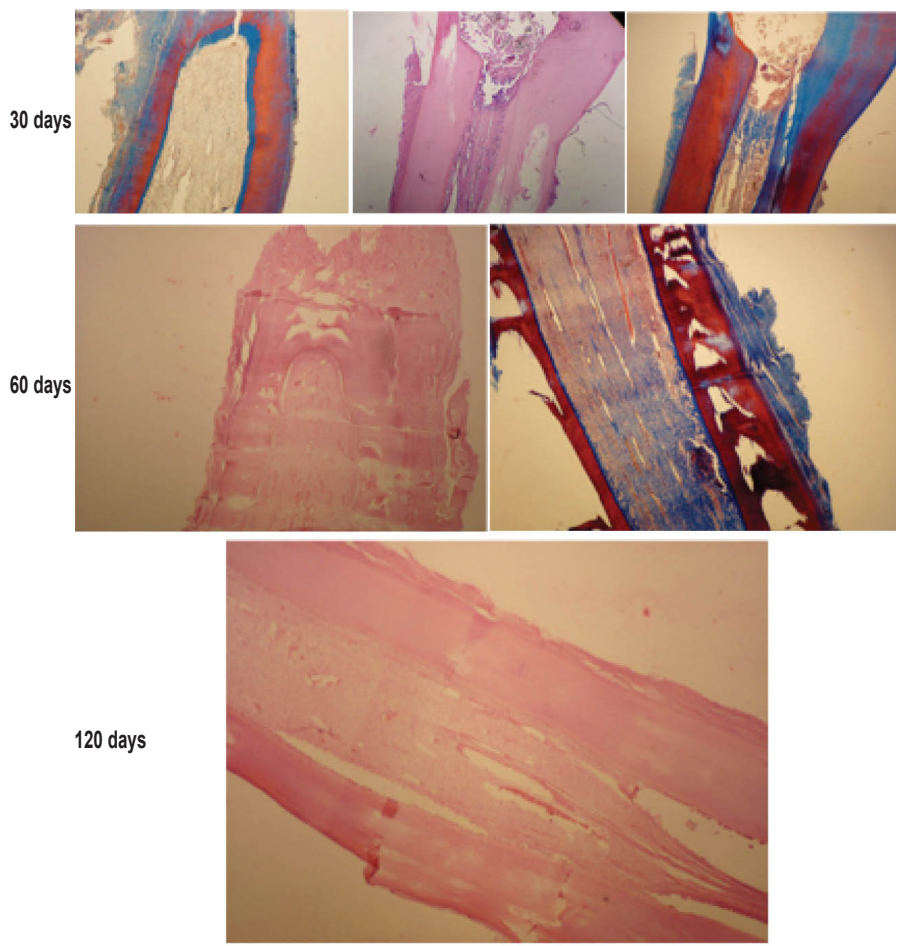

Fig. 2. Representative histological views of periodontal/bone compartment after 30 days, 60 days, and 120 days of periodontal/ bone remodeling in tooth extraction defects of osteoporotic sheep (different stains)

At 12 weeks, defect healing was mainly characterized by an ongoing bone formation and mineralization. In particular, histological observation revealed a continuous filling of the intertrabecular spaces in all of the animals and subsequently a transformation into primary osteons. This was particularly true for the central parts of the defect areas. However, a similar amount of bone resorption was identifiable in the peripheral compartments, obviously resulting from a retarded bone remodelling in our osteoporotic sheep model (Fig. 3).

The ideal «tool» for the scientific evaluation of new surgical materials and procedures is an appropriate animal model. This allows both a qualitative, histological description of the healed site, and a quantitative or histometric analysis of the amount of new tissue produced. Newton B. et al. [12] commented that «strategies for selecting an experimental animal model also require clear understanding of spontaneous bone defect healing, to correlate experimental data obtained from humans. Interspecies differences may be overcome thanks to the knowledge of healing in «criticial size defects».

Various animal models have been utilized to investigate the osteoporotic condition in order to facilitate preclinical testing of newly developed biomaterials and to evaluate new treatment options in dental implantology. The ideal animal model should mimic the anatomy, biomechanics, cell biology and pathological changes seen in the human skeleton [16], and at the same time should be reproducible, meet appropriate ethical standards and be economical and efficient. Most basic investigations of osteoporosis have been conducted in the rat [4], but this model has limited utility because it lacks true lamellar bone and hence does not undergo trabecular remodelling in the same way as human bone, especially in younger animals [14]. Long-term bone loss following ovariectomy alone in the rat is not as dramatic as the bone loss in postmenopausal women [1] and cortical bone studies are limited due to the absence of Haversian systems.

Consequently, there is a need for a large animal model for use in osteoporosis- (age-) related research to facilitate preclinical evaluation of biomaterials and dental implants as well as surgical and mechanical treatments in alveolar bone regeneration.

The amount of growth factors and the number of bone cells capable of being stimulated by a bioactive surface of newly developed implants or by bone substitute materials as well as by stem-cell supported dental bone regeneration decrease as a consequence of patient aging and conditions such as estrogen deficiency [1]. Therefore, the challenge for the future is to extend these findings to studies on compromised bones with osteopenia and osteoporosis and to apply the concept to humans with aging bones and degenerative diseases. The present proof of principle study was designed to evaluate the influence of tooth extraction and of a creating of an acute $12 \mathrm{~mm}$ bone defect on bone remodeling in a osteoporotic sheep model assessing:

(a) the osteoporotic sheep mandible as a standardized model;

(b) the osteoporotic deficiency as simulating aging processes;

(c) the bone quality of two different experimental sites by histological analyses and lower jaw BMD measurement.

Perhaps the most significant observation from this proof of principle study, which was undertaken
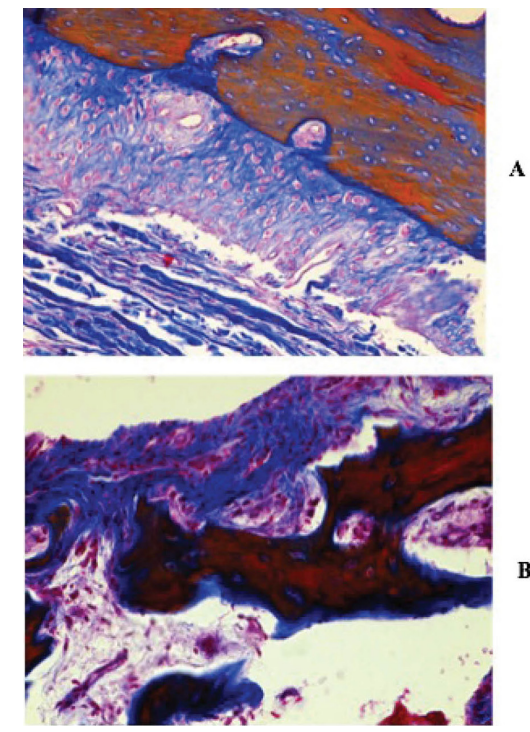

Fig. 3. Representative histological views of $12 \mathrm{~mm}$ CSD in osteoporotic sheep at base-line (A) and after 12 weeks (B) of bone remodeling (HE stain, van Gieson`s stain). In particular, new trabeculae of woven invaded within and circumferentially around the defect area. Defect filling was mainly characterized by an ongoing bone formation and mineralization, resulting in a continuous filling of the intertrabecular spaces. This was particularly true for the central part of the defect areas 
to characterize a potential large animal model of osteoporosis, was the progressive reduction in BMD at two anatomical sites (post extraction site of frontal teeth and $12 \mathrm{~mm}$ acute bone defect) within 6 months after ovarectomy. The total ovariectomy that resulted in this bone deficit did not adversely affect the general health of the sheep, and even though all animals gained weight during the course of the study they were not obese. Bone loss at both anatomical sites was in excess of $25 \%$ which is sufficient to categorize these animals as osteoporotic supporting the stated hypothesis and suggests that the mechanism of bone loss could differ temporally as well as anatomically.

In general, it was observed that both of treatment procedures resulted in considerable histological values typically for osteoporotic changes during the entire healing period of 30 days, 60 days, and 120 days for the periodontal/bone compartment and for 12 weeks after creation of an acute $12 \mathrm{~mm}$ bone defect in the osteoporotic sheep pairs. While all of the animals exhibited a pronounced bone formation in the center of the defect areas, the ingrowth of bone generally appeared to be lower in comparison with the native bone structures at the basic time.

\section{References}

1. Chailurkit L. O., Ongphiphadhanakul B., Piaseu N. [et al.] Biochemical markers of bone turnover and response of bone mineral density to intervention in early postmenopausal women: an experience in a clinical laboratory. Clin. Chem. 2001; 47:1083-1088.

2. Duncan W. J. Sheep mandibular animal models for dental implantology research. A thesis submitted for the degree of Doctor of Philosophy at the University of Otago, Dunedin, New Zealand, 2005.

3. Duncan, W. J. Modelling bone regeneration in ovis aries. In: Bartold, P. \& Nagata, T., eds. The Past, Present and Future of Periodontology. Proceedings of the 10th Asian Pacific Society of Periodontology Meeting, 2014.

4. Egermann M., Goldhahn J., Schneider E. Animal models for fracture treatment in osteoporosis. Osteoporosis International. 2005;16 (Suppl 2):S129-S138.

5. FDA Division of Metabolism and Endocrine Drug Products Food and Drug Administration Guidelines for preclinical and clinical evaluation of agents used in the prevention or treatment of postmenopausal osteoporosis, Washington, DC, 1994.

6. Grimm W.-D., Dannan A., Becher S. [et al.] The Ability of Human Periodontium-derived Stem Cells to Regenerate Periodontal Tissues-A Preliminary in vivo Investigation. J. Periodont. Rest. Dentistry. 2011:31(6):e94-e101.

7. Grimm W-D., Giesenhagen B., Hakki S. [et al.] Translational Research and Therapeutic Applications of Neural Crest-Derived Stem Cells in Regenerative Periodontology. Curr. Oral. Health. Rep. 2015. doi: 10.1007/s40496-015-0067-6

8. Grimm W.-D., Fritsch T., Giesenhagen B. [et al.] Neural crest-related stem cells of oral origins in vitro and used in osteoporotic sheep model for being investigated due to therapeutic effects in alveolar bone regeneration. Medical News of North Caucasus. 2016;11(2):192-196. doi: $10.14300 / m n n c .2016 .11034$

9. Goldhahn J., Jenet A., Schneider E. [et al.] Slow rebound of cancellous bone after mainly steroid-induced osteoporosis in ovariectomized sheep. J. Orthop. Trauma. 2005;19:23-28.
Bone loss has been reported previously at various skeletal sites in sheep following ovariectomy, chronic steroid therapy, but in none of these studies, could these animals be classified as osteoporotic by standard definitions $[1,12,16]$. Other factors such as trabecular architecture, tissue properties and microdamage are important for maintaining the mechanical integrity of alveolar bone and should be investigated further in this model. Nonetheless, the significant impact of osteoporosis confirms the suitability of this model for comparative alveolar bone healing research.

Conclusions. Within the limits of the present study, it was concluded that both of used models, the tooth extraction site model and the acute $12 \mathrm{~mm}$ defect model of osteoporotic sheep have shown efficacy for being used in comparative alveolar bone healing research studies. We will be able to use this model for investigating the effect of stem cell supported treatments in regeneration of segmental mandibular bone defects in osteoporotic sheep using ovine NCSCs from palate $[7,8,17]$.

Acknowledgements. We thanks Prof. F. Witte, Berlin, Germany, for providing the PMMA histology and for the very helpful comments of Prof. W. Duncan, Otago, New Zealand, and of Prof. SS Hakki, Konya, Turkiye.

10. Goldhahn J., Suhm N., Goldhahn S. [et al.] Influence of osteoporosis on fracture fixation - a systematic literature review. Osteoporosis International. 2008;19(6):761772.

11. Klein K., Zamparo E., Kronen P. W. [et al.] Bone augmentation for cancellous bone-development of a new animal model. BMC Musculoskelet Disord. 2013;14:200. doi: 10.1186/1471-2474-14-200

12. Newton B. I., Cooper R. C., Gilbert J. A. [et al.] The ovariectomized sheep as a model for human bone loss. J. Comp. Pathol. 2004;130:323-326. doi: 10.1016/j. jсра.2003.12.007

13. Stadelmann V. A., Gauthier O., Terrier A. Implants delivering Bisphosphonate locally increase periprosthetic bone density in an Osteoporotic Sheep Model. A pilot study. European Cells and Materials. 2008;16:10-16.

14. Thompson D. D., Simmons H. A., Pirie C. M. [et al.] FDA Guidelines and animal models for osteoporosis. Bone. 1995;17:125S-133S. doi: 10.1016/87563282(95)97353-H

15. Trisi P., Berardini M., Falco A., Podaliri Vulpiani M. New Osseodensification Implant Site Preparation Method to Increase Bone Density in Low-Density Bone: In Vivo Evaluation in Sheep. Implant Dent. 2016;25(1):24-31. doi: 10.1097/ID.0000000000000358

16. Turner A. S. Animal models of osteoporosis - necessity and limitations. Eur. Cell. Mater. 2001:1:66-81.

17. Widera D., Zander C., Heidbreder M. [et al.] Adult palatum as a novel source of neural crest-related stem cells. Stem. Cells. 2009;27:1899-910.

18. Willbold E., Witte F. Histology and research at the hard tissue-implant interface using Technovit 9100 New embedding technique. Acta Biomaterialia. 2010;6:44474455.

19. Zarrinkalam M. R., Beard H., Schultz C. G., Moore R. J. Validation of the sheep as a large animal model for the study of vertebral osteoporosis. Eur. Spine J. 2009;18(2):244-253. doi: 10.1007/s00586-008-0813-8 PMCID: PMC289934

\section{About authors:}

Sirak Sergey, MD, PhD, Professor, Head of Department for Dentistry; tel.: +7865235-05-51; e-mail: sergejsirak@yandex.ru

Shchetinin Evgeny, MD, PhD, Head of Department for Pathological Physiology; tel.: +7865235-26-84; e-mail: ev.cliph@rambler.ru

Bobryshev Dmitry, MD, CMSc, Head of Center for Personalized Medicine; tel.: +7(8652)357369; e-mail: innova@stgmu.ru

Fritsch Tilman, MD, PhD, Professor of Implantology; tel.: +49865164622; e-mail: tilmanf@hotmail.com

Giesenhagen Bernd, MD, PhD, Professor of Implantology; tel.: +4956140085362; e-mail: b.giesenhagen@gmx.de 